\title{
Rapid Identification of Heterotrophic, Thermophilic, Spore-Forming Bacteria Isolated from Hot Composts
}

\author{
MICHEL BLANC, * LAURENT MARILLEY, TRELLO BEFFA, AND MICHEL ARAGNO \\ Laboratoire de Microbiologie, Université de Neuchâtel, CH-2007 Neuchâtel, Switzerland
}

\begin{abstract}
The restriction enzyme profiles of $16 \mathrm{~S}$ ribosomal DNAs (rDNAs) amplified by PCR from thermophilic heterotrophic bacterial strains isolated from composts were compared with those of reference strains. This allowed us to assign all but 1 of 16 strains to four different Bacillus species (namely, Bacillus stearothermophilus, Bacillus pallidus, Bacillus thermoglucosidasius, and "Bacillus thermodenitrificans"). This study showed that PCR restriction analysis of $16 \mathrm{~S}$ rDNA contributes to rapid and reliable identification of newly isolated strains belonging to recognized species.
\end{abstract}

A few studies have reported the presence of thermophilic bacteria in hot compost $(3,4,7,19,20)$. Strom $(19,20)$ isolated more than 750 heterotrophic spore-forming strains from compost; very few of these strains grew at temperatures above $60^{\circ} \mathrm{C}$, and growth at $65^{\circ} \mathrm{C}$ was restricted to Bacillus coagulans (type A) and Bacillus stearothermophilus. Until recently, only strains related to $B$. stearothermophilus were identified from the hottest compost samples screened $\left(65\right.$ to $\left.69^{\circ} \mathrm{C}\right)(7,19,20)$. The great diversity of thermophilic bacteria related to the genus Bacillus has frequently been emphasized $(16,22)$, but it appears that only a few of the isolates have properly been identified to date. The morphology of sporulating cells, the shape of colonies, and growth abilities have proved to be insufficient for unequivocal identification of Bacillus strains (10, 11). The purpose of the present study was to identify heterotrophic, thermophilic, spore-forming strains isolated from hot composts by using a rapid molecular method based on the restriction profiles of $16 \mathrm{~S}$ ribosomal DNA (rDNA) amplified by PCR.

Serial dilutions of compost sample suspensions were carried out in five different media. B and DN media consisted simply of nutrient broth (Merck, Darmstadt, Germany); DN medium was supplemented with $2 \mathrm{~g}$ of $\mathrm{KNO}_{3}$ per liter. GA, P, and PN media were synthetic media composed of a basal mineral medium (1) supplemented with various growth substrates at a concentration of $2 \mathrm{~g} \mathrm{liter}^{-1}$ [GA medium contained D-glucose and sodium acetate; $\mathrm{P}$ medium contained sodium pyruvate; $\mathrm{PN}$ medium contained sodium pyruvate and $\left.\left.\left(\mathrm{NH}_{4}\right)_{2} \mathrm{SO}_{4}\right)\right]$. The cultures were incubated under air at $65^{\circ} \mathrm{C}$ for 1 to 6 days, and pure colonies were isolated by repeated streaking on the same media solidified with agar. Colonies varying in appearance were picked deliberately to try to increase the number of different species isolated (the second and third letters of the compost strain designations in Fig. 1 refer to the isolation medium). Pure strains were then routinely cultivated at $60^{\circ} \mathrm{C}$ on B medium supplemented with $2 \mathrm{~g}$ yeast extract per liter and solidified with agar (NAY medium). The type and reference strains are listed in Table 1.

\footnotetext{
* Corresponding author. Mailing address: Laboratoire de Microbiologie, Université de Neuchâtel, Rue Emile-Argand 11, CH-2007 Neuchâtel, Switzerland. Phone: 41-32-718.22.60. Fax: 41-32-718.22.31. Email: Michel.Blanc@bota.unine.ch.
}

Metabolic tests were carried out at $55^{\circ} \mathrm{C}$ with API $20 \mathrm{NE}$ strips (BioMérieux, Marcy-l'Etoile, France) by using a few fresh colonies suspended in the basal mineral medium supplemented with $0.1 \mathrm{~g}$ of yeast extract per liter and $0.1 \mathrm{~g}$ of peptone per liter, unless indicated otherwise. Starch hydrolysis was tested in the basal mineral medium as described by Smibert and Krieg (17). Anaerobic growth (denitrification) was tested on NAY medium plates supplemented with $10 \mathrm{~g}$ of $\mathrm{KNO}_{3}$ per liter. Cultures were incubated for 4 days at $60^{\circ} \mathrm{C}$ in desiccator jars; oxygen was eliminated by using an Anaerocult IS bag (Merck).

DNA extraction and purification were carried out as previously described (4), except that the cells were treated with lysozyme prior to guanidium thiocyanate DNA extraction (13). The 16S rDNA was selectively amplified by using oligonucleotide primers designed to anneal to bacterial 16S rRNA genes as previously described (4). The reaction conditions were as follows: 1 to $5 \mathrm{ng}$ of template DNA, $0.8 \mathrm{U}$ of Goldstar Taq DNA polymerase (Eurogentec, Seraing, Belgium), $5 \mu \mathrm{l}$ of $10 \times$ Goldstar PCR buffer, $1.5 \mathrm{mM}$ (final concentration) $\mathrm{MgCl}_{2}$, $0.25 \mu \mathrm{M}$ forward primer, $0.25 \mu \mathrm{M}$ reverse primer, and each deoxynucleoside triphosphate at a concentration of $170 \mu \mathrm{M}$ were combined in a total volume of $50 \mu \mathrm{l}$. Amplification was carried out in a model PTC-100 thermal cycler (MJ Research, Inc., Watertown, Mass.) with the following program: a preliminary denaturation step was carried out at $95^{\circ} \mathrm{C}$ for $1 \mathrm{~min}$ and was followed by 35 cycles consisting of $30 \mathrm{~s}$ at $94^{\circ} \mathrm{C}$ (denaturation), $30 \mathrm{~s}$ at $62^{\circ} \mathrm{C}$ (except for the three first touchdown cycles, which were successively at 68,66 , and $64^{\circ} \mathrm{C}$ ), and $1 \mathrm{~min}$ at $72^{\circ} \mathrm{C}$ (extension). For restriction enzyme digestion, $50 \mathrm{ng}$ of the PCR product was mixed with $2 \mathrm{U}$ of Hae III or $1 \mathrm{U}$ of HinfI (New England Biolabs, Inc., Beverly, Mass.), TaqI, or Rsa I (Gibco BRL) and incubated for $4 \mathrm{~h}$ according to the manufacturer's instructions. PCR products and restriction digests were separated by electrophoresis as previously described (4).

Phenotypic characterization. The strains studied were isolated from 2- to 80-day-old composts as previously described (4); the sample temperatures ranged from 57 to $78^{\circ} \mathrm{C}$. All of the strains were rods and formed oval endospores. Spore position varied from central to terminal. These strains were initially supposed to belong to the genus Bacillus, according to the description of Gordon et al. (8). Their maximum growth temperatures were between 65 and $72^{\circ} \mathrm{C}$. Except for the Bacillus pallidus group, as pointed out previously (22), all of the strains 
TABLE 1. Reference strains used in this study

\begin{tabular}{|c|c|c|}
\hline Species & Strain $^{a}$ & $\begin{array}{l}\text { EMBL 16S } \\
\text { rDNA sequence } \\
\text { accession no. }\end{array}$ \\
\hline B. stearothermophilus & $\underset{(6)^{h}}{\operatorname{DSM} 22^{\mathrm{T}}}\left(=\operatorname{ATCC} 12980^{\mathrm{T}}\right)$ & X60640 (2) \\
\hline B. stearothermophilus & DSM 494 (12) & $\mathrm{NA}^{c}$ \\
\hline B. thermoglucosidasius & $\begin{array}{l}\operatorname{DSM} 2542^{\mathrm{T}}\left(=\operatorname{ATCC} 43742^{\mathrm{T}}\right) \\
\quad(21)\end{array}$ & X60641 (2) \\
\hline Bacillus sp. & DSM 6499 (18) & NA \\
\hline "B. thermodenitrificans" & DSM $465(=$ ATCC 29492) (9) & Z26928(14) \\
\hline B. pallidus & $\underset{(15)}{\operatorname{DSM} 3670^{\mathrm{T}}}\left(=\operatorname{ATCC} 51176^{\mathrm{T}}\right)$ & $\mathrm{Z} 26930(14)$ \\
\hline Bacillus sp. & DSM $2349(5)$ & Z26929(14) \\
\hline
\end{tabular}

"DSM, Deutsche Sammlung von Mikroorganismen, Braunschweig, Germany; ATCC, American Type Culture Collection, Rockville, Md.

${ }^{b}$ The numbers in parentheses are reference numbers.

c NA, not available.

could grow anaerobically with nitrate as a respiratory substrate. Glucose, mannose, and maltose were utilized as growth substrates by all but two strains, as reported previously for most thermophilic bacilli (22), and starch was hydrolyzed by most strains (data not shown).

PCR restriction analysis (PRA) of $16 S$ rDNA. The restriction fragment length polymorphism profiles of $16 \mathrm{~S}$ rDNAs (digested with HaeIII) of the strains isolated from composts and of the reference strains listed in Table 1 formed five groups with distinctive patterns (Fig. 1). To avoid confusion with primer dimer bands, and because of the detection threshold, restriction fragments shorter than 90 bp were disregarded.

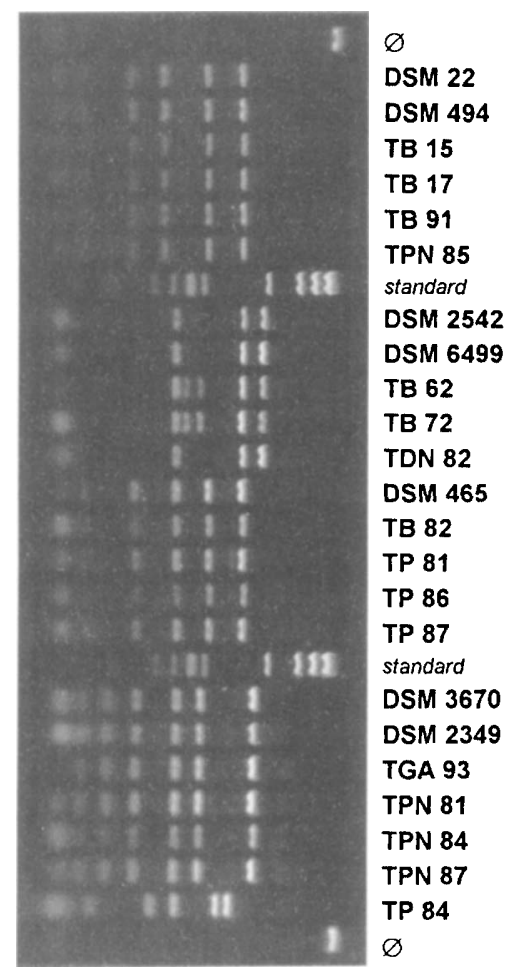

FIG. 1. PRA profiles of $16 \mathrm{~S}$ rDNAs, selectively amplified and digested with HaeIII, of Bacillus reference strains and of 16 strains isolated from hot composts. $\varnothing$, undigested amplification product; standard, $\Phi$ X174RF digested with Hae III. See Table 1 for reference strains.
These profiles permitted us to group all but 1 of the 16 strains with the seven reference strains belonging to four species (namely, B. stearothermophilus, B. pallidus, Bacillus thermoglucosidasius and "Bacillus thermodenitrificans"). The profiles obtained with restriction enzymes HinfI and RsaI showed no distinctive patterns for the strains tested (data not shown).

Theoretical restriction profiles calculated from $16 \mathrm{~S}$ rDNA sequences available in the EMBL nucleotide sequence database were compared with the results obtained for our strains and for the reference strains. Within the first group, the profiles of reference strains DSM 22 and DSM 494 matched the theoretical profile calculated from the corresponding sequence of B. stearothermophilus (EMBL accession no. X60640). In the second group, the profile of reference strain DSM 2542 matched the theoretical profile of the sequence EMBL X60641. No 16S rDNA sequence could be found for strain DSM 6499. However, the restriction profiles did show that this strain was related to $B$. thermoglucosidasius DSM 2542, as described previously (18).

In the third group, the profile of the reference strain " $B$. thermodenitrificans" DSM 465 matched the theoretical profile of the corresponding sequence EMBL Z26928, except for the calculated 206-bp fragment that appeared to be $240 \pm 5 \mathrm{bp}$ long on the gel, and this was also true for the four related compost strains. This may have been due to the lack of recognition of a restriction site that caused a 25-bp fragment to remain attached to the 206-bp fragment. TaqI restriction profiles confirmed that this group was distinct from the three other groups (data not shown).

In the fourth group, the profiles of reference strains DSM 3670 and DSM 2349 matched the theoretical profiles of the corresponding sequences EMBL Z26930 and EMBL Z26929, respectively. Strain DSM 2349 could be linked to $B$. pallidus DSM 3670 , as has been proposed in previous studies $(14,22)$.

The profile of strain TP-84 could not be related to any $16 \mathrm{~S}$ rDNA sequence available for thermophilic bacilli.

PRA profiles are a powerful tool for identifying new strains related to heterotrophic thermophilic bacilli. The results obtained showed, however, that in some cases (e.g., the " $B$. thermodenitrificans" group [see above]) the digestion profiles of new strains should be compared with profiles obtained experimentally from reference strains, and the restriction profiles calculated from published sequences should not be relied on.

By using five different isolation media, we showed that there is a taxonomically and metabolically diverse population of heterotrophic thermophilic spore-forming bacteria in thermogenic composts. Few growth tests had diagnostic value for any single group of strains; only the strains related to $B$. pallidus had common features (particularly the absence of growth under denitrificating conditions) that clearly distinguished them from the other groups. Strain TP-84, despite its lack of reactivity with most of the substrates tested, like Bacillus thermocloacae strains (22), could not be related to this species by its PRA profile. Phenotypic tests can therefore not be relied on for taxonomic grouping of new Bacillus strains, while PRA of $16 \mathrm{~S}$ rDNA appears to be a promising tool for rapid and reliable identification of newly isolated strains of recognized species.

This work was supported by grant 5002-038921 from the Swiss National Science Foundation.

We are grateful to Nicole Jeanneret, Johanna Lott Fischer, PierreFrançois Lyon, and Valérie Mauron for collaboration and technical assistance. We thank Catherine Fischer, Claudio Valsangiacomo, Jean Mariaux, and Jean-Marc Neuhaus for their help. 


\section{REFERENCES}

1. Aragno, M. 1992. Thermophilic, aerobic, hydrogen-oxidizing (Knallgas) bacteria, p. 3917-3933. In A. Balows, H. G. Trüper, M. Dworkin, W. Harder, and K.-H. Schleifer (ed.), The prokaryotes, 2nd ed. Springer-Verlag, New York, N.Y.

2. Ash, C., J. A. E. Farrow, S. Wallbanks, and M. D. Collins. 1991. Phylogenetic heterogeneity of the genus Bacillus revealed by comparative analysis of small-subunit-ribosomal RNA sequences. Lett. Appl. Microbiol. 13:202-206.

3. Beffa, T., M. Blanc, and M. Aragno. 1996. Obligately and facultatively autotrophic, sulfur- and hydrogen-oxidizing thermophilic bacteria isolated from hot composts. Arch. Microbiol. 165:34-40.

4. Beffa, T., M. Blanc, P.-F. Lyon, G. Vogt, M. Marchiani, J. Lott Fischer, and M. Aragno. 1996. Isolation of Thermus strains from hot composts (60 to $80^{\circ} \mathrm{C}$ ). Appl. Environ. Microbiol. 62:1723-1727.

5. Daron, H. H. 1973. Nutritional alteration of the fatty acid composition of a thermophilic Bacillus species. J. Bacteriol. 116:1096-1099.

6. Donk, P. J. 1920. A highly resistant thermophilic organism. J. Bacteriol. 5:373-374.

7. Fujio, Y., and S. J. Kume. 1991. Isolation and identification of thermophilic bacteria from sewage sludge compost. J. Ferment. Bioeng. 72:334-337.

8. Gordon, R. E., W. C. Haynes, and C. Hor-Nay Pang. 1973. The genus Bacillus. Agricultural handbook no. 427. Agricultural Research Service, U.S. Department of Agriculture, Washington, D.C.

9. Klaushofer, H., and F. Hollaus. 1970. Zur Taxonomie der Hochthermophilen, in Zuckerfabrikssaften vorkommenden aeroben Sporenbildner. Z Zuckerind. 20:465-470.

10. Logan, N. A., and R. C. W. Berkeley. 1981. Classification and identification of members of the genus Bacillus using API tests, p. 105-140. In R. C. W. Berkeley and M. Goodfellow (ed.), The aerobic endospore-forming bacteria Academic Press, Ltd., London, United Kingdom.

11. Logan, N. A., and R. C. W. Berkeley. 1984. Identification of Bacillus strains using the API system. J. Gen. Microbiol. 130:1871-1882.

12. Manachini, P. L., A. Craveri, and A. Guicciardi. 1968. Composizione in basi dell'acido desossiribonucleico di forme mesofile termofacoltative e termofile dell'genere Bacillus. Ann. Microbiol. Enzimol. 18:1.

13. Pitcher, D. G., N. A. Saunders, and R. J. Owen. 1989. Rapid extraction of bacterial genomic DNA with guanidium thiocyanate. Lett. Appl. Microbiol. 8:151-156.

14. Rainey, F. A., D. Fritze, and E. Stackebrandt. 1994. The phylogenetic diversity of thermophilic members of the genus Bacillus as revealed by $16 \mathrm{~S}$ rDNA analysis. FEMS Microbiol. Lett. 115:205-212.

15. Scholz, T., W. Demharter, R. Henzel, and O. Kandler. 1987. Bacillus pallidus sp. nov., a new thermophilic species from sewage sludge. Syst. Appl. Microbiol. 9:91-96.

16. Sharp, R. J., P. W. Riley, and D. White. 1991. Heterotrophic thermophilic bacteria, p. 19-50. In J. K. Kristjansson (ed.), Thermophilic bacteria. CRC Press, Inc., Boca Raton, Fla.

17. Smibert, R. M., and N. R. Krieg. 1994. Phenotypic characterization, p. 607-654. In P. Gerhardt, R. G. E. Murray, W. A. Wood, and N. R. Krieg (ed.), Methods for general and molecular bacteriology. American Society for Microbiology, Washington, D.C.

18. Stalder, V., M. Marchiani, M. Aragno, and R. Bachofen. 1994. Characterization and identification of a new strain of esterase-producing Bacillus thermoglucosidasius "EAEC" from an aerated thermophilic sewage sludge. Microbiol. Res. 149:1-7.

19. Strom, P. F. 1985. Effect of temperature on bacterial species diversity in thermophilic solid-waste composting. Appl. Environ. Microbiol. 50:899-905.

20. Strom, P. F. 1985. Identification of thermophilic bacteria in solid-waste composting. Appl. Environ. Microbiol. 50:906-913.

21. Suzuki, Y., T. Kishigami, K. Inoue, Y. Mizoguchi, N. Eto, M. Takagi, and S. Abe. 1983. Bacillus thermoglucosidasius sp. nov., a new species of obligately thermophilic bacilli. Syst. Appl. Microbiol. 4:487-495.

22. White, D., R. J. Sharp, and F. G. Priest. 1993. A polyphasic taxonomic study of thermophilic bacilli from a wide geographical area. Antonie van Leeuwenhoek 64:357-386. 